\title{
One White Shirt
}

\section{Lucia Nardo}

Mrs B Dusted the framed photograph and placed it on a crocheted doily on the sideboard. In the snap, his face was impassive except for a permanent pull at the edges of his lips. She could never decide whether he had been about to smile or not. She had come to terms with the fact she had never really known his true thoughts. 'You were not one for talking,' she said, 'at least these days you listen...' Mrs B gave him a hesitant smile, '... after a fashion.'

She had set up the ironing board in the lounge room, placing it near the small gas fire that gave off a soft glow as it pressed the icy day back from the windows. 'I've waited this whole year to do this,' she said to him, 'but that doesn't mean I wasn't thinking about you.' She smoothed down the apron she wore over her faded floral dress, topped with a pilling hand-knitted cardigan.

Mrs B set to ironing the pile of rumpled clothes. 'You were always different from your brother and sisters. Always drawing and full of big ideas, that was you! You wanted to travel all over. You caused me more worry than all the rest put together.' She reached out and put a gentle finger to his cheek. 'And you were so sensitive. You always broke easily. Then, when Maggie went...' Mrs B bit her lip and shook her head, '...such a sweet girl and good wife, your Maggie was. I know how hard it is to go on without the person you love. I don't blame you for being so angry, but anger is always hungry.'

With arthritic fingers bent permanently at an angle, Mrs B worked her way through the stack. Intermittently, she rested the iron on its heel and rubbed her hand, her face twisting as the aching engulfed her. Her thin wedding band slipped along her finger, stopped from falling away by a swollen knuckle.

Despite the pain, today was a good day. Today she could function. Today she had a purpose. Not like the days when she lay in bed, blanketed in numbness until long afternoon shadows filled the room. 
You took off for such a long time after that. Don't know where you got to; not even a phone call or a letter. But then, grief is such a heavy burden and you were too exposed to it. Worst of it was that I couldn't help anymore; not like when you were little.'

Eighty-one years of life had crumpled Mrs B to lines and creases. A salt-of-the earth type from generations of labouring workers, she was widowed young and left to raise a brood of four. Family was everything to her; only her children had kept her going.

'The train ride to Melbourne for the funeral wasn't easy. Eleven hours it took to get there from Adelaide. Funny how it seemed longer coming home; must have been the load I was carrying. I'd never travelled that far before. Who would've thought it'd stop at all those places: Bordertown, Nhill, Dimboola? Funny names, aren't they?' She gave a little snort and stopped ironing to dab the sides of her mouth with a lace handkerchief that she had pulled from her cardigan sleeve.

Her hands trembled as she picked up the last shirt from the wicker basket and set it on the ironing board. It was brilliant white and the culmination of her ironing task. She bent her tiny frame firmly over the iron until the steam hissed out of each side, pressing the first sleeve and cuff with absorbed attention. The air was heavy with the scent of the freshly ironed cotton. She paused and held up the sleeve for inspection.

Mrs B dabbed her eyes. She turned the white shirt over and focused her attention on the other sleeve. She ironed it flat, her small brow creased tight in concentration as she navigated the iron like an icebreaker cutting into the wrinkled material, leaving smoothness in its wake.

'That housemate of yours called me after the police had already come and gone. He waited for two days before he let me know!' Mrs B swallowed hard. 'After the funeral, I stayed on an extra week just to find the courage to go and see where you'd been living.' Mrs B put a hand to her throat recalling the run down house, wondering how his life had spiralled to that lonely end. 'I wanted to get your things; didn't want anyone else going through them. That horrible man had put them out in that leaky garden shed. 
He took me to the door and pointed; there they were-three old cardboard boxes. All you had left. He didn't even seem to care they'd got wet.'

The mustiness of the box that had been most water affected remained with her. It was a scent that still snatched her attention in the most unexpected moments, taking away her breath as the shock was delivered anew. It had been filled with books; classic literature, most wet to pulp and unsalvageable. The ones that survived she had packed into a large plastic zippered shopping bag, along with a photograph of Maggie, a sketchbook, clothing, his watch, a battered wallet containing his license and thirty-seven dollars in notes and change.

She drew on the weight of her anguish to press into the material, as if her efforts could smooth out life again; could restore its crispness.

'It was so heavy to carry that bag back to the train station. I'm not as fit as I used to be and my arthritis plays up something shocking in the winter.' She swallowed to hold back tears that came with the heaviness of the memory. 'That's what it came down to, three cardboard boxes. Imagine...' Mrs B's voice cracked and she scrunched her eyes, warding off the stark image. 'It wasn't much to show for all your years of work. All that money you gave away after you worked so hard to earn it. I never understood why you did, but I was proud of how much you cared about others. You helped so many people. You deserved to have more friends, especially after Maggie went.'

She looked into his eyes, searching, until the tears surged and made it impossible to discern his face. 'I cried all the way back to Adelaide. People turned their faces away from me. The tears of others are embarrassing when you don't understand what they're for.' Mrs B frowned. 'I just can't let go of the idea that it was somehow my fault. That I should have known; that I could have done something.' She considered those beliefs for the millionth time. She had thought and thought about them until her insides felt rusted away by tears and the passing days. In the remaining emptiness there was only the clang of the ongoing question: where did I fail you?

Mrs B rubbed her hand until the pain eased then returned to her task. 
She ironed each front panel of the shirt, paying particular attention to the piping on the pocket, not letting it pucker. 'Now, this shirt came special,' she told him when she found her voice again, 'Came in a sealed plastic bag the morgue sent back. It was hard to get it clean but I kept at it until it was done. I got rid of those terrible stains.'

Mrs B shuddered and bent forward, her thin arms wrapped around her tiny middle. She could still see the dark blood; blood that had soaked into the white collar when the rope he had noosed around his neck rasped away his skin as he let himself drop from the pergola beam. Blood that had dried in lines that told a fragment of his story. He had left no note to explain the rest.

Her wail travelled throughout the small home in which the aging walls had been shored up with his memory and where now, all she could breathe in was loss. If only she had known of his life, his struggles, his pain. She tortured herself with images of his last moments, wondering what he had been thinking; saw him securing the rope when his depression had garnered enough energy. She imagined and imagined until her eyes burned with hot tears that failed to wash away the vision. Then Mrs B tried to summon the will to forgive him, not knowing if it would ever come.

When she had spent the wave of grief, the room fell quiet again except for the hiss of the heater. Mrs B grew calm and drew up her small frame. 'I suppose I'll have to learn to live with the whys?' She wiped her face, smoothing her hands over the network of wrinkles that had formed river-ways for all the tears she had already cried and for those that were yet to come.

At the ironing board once more, she steeled her residual strength and finished folding the white shirt, now washed pure of any trace of its last wearing. She shuffled into his room carrying the shirt across her frail arms.

Mrs B stood for a long time at the open door of his childhood wardrobe, as if considering the altar she had made. She had found a place for everything; the vestiges of the cardboard boxes, his remaining clothing that she had washed, pressed and hung. 
The white shirt she placed separately on the middle shelf, giving it a final tender smoothing down, stopping her hand over the pocket as if she expected to feel his heartbeat beneath. The shirt felt cool, the life of the warm iron now dissipated.

Mrs B wept.

Closing the door, she wiped her aching hands on her apron, so defining the end of the task with which she had marked his anniversary. It was the last thing she could do for her son. 